\title{
CONSUMPTION OF BENZODIAZEPINES WITHOUT PRESCRIPTION AMONG FIRST-YEAR NURSING STUDENTS AT THE UNIVERSITY OF GUAYAQUIL, SCHOOL OF NURSING, ECUADOR
}

\author{
Nivia Pinos Paredes ${ }^{1}$ \\ Adriana Inocenti Miasso ${ }^{2}$ \\ Carlos Renato Tirapelli ${ }^{2}$
}

Pinos Paredes N, Miasso AI, Tirapelli CR. Consumption of benzodiazepines without prescription among first-year nursing students at the University of Guayaquil. Rev Latino-am Enfermagem 2008 maio-junho; 16(especial):634-9.

This study aimed to determine the consumption of benzodiazepines without prescription among firstyear students from a nursing school of a public University in Ecuador. This is a descriptive, transversal and explanatory study with a quantitative approach. A questionnaire was used for data collection. The population studied was of 181 students. The results showed that $10.5 \%$ of the students had consumed benzodiazepine without prescription once in their lives. Of these, $6.1 \%$ consumed benzodiazepine in the last year, and $3.9 \%$ are currently consuming it. The diazepam was the most consumed BZD without prescription and pharmacies, were the place of higher access. The main reasons for the benzodiazepine consumption were: insomnia, anxiety, stress, depression, family and economical problems. The use of benzodiazepines with non-medicinal purposes is related to problems such as memory loss, retirement syndrome and sedation. When benzodiazepines are consumed jointly with alcohol or other drugs they can lead to coma or death. This study shows the serious consequences benzodiazepines cause when used by nursing students in Ecuador.

DESCRIPTORS: auto medication; GABA-A receptors; students, nursing

\section{CONSUMO DE BENZODIACEPINAS SIN PRESCRIPCIÓN MÉDICA EN LOS/AS ESTUDIANTES DE PRIMER AÑO DE LA ESCUELA DE ENFERMERÍA DE LA UNIVERSIDAD DE GUAYAQUIL, ECUADOR}

La finalidad de este estudio fue determinar el consumo de benzodiacepinas sin prescripción en estudiantes del primer año de enfermería de una universidad pública de Ecuador. Se trata de un estudio transversal, descriptivo y exploratorio, con aproximación cuantitativa. Un cuestionario fue usado para la recolecta de los datos. La población estudiada fue compuesta por 181 estudiantes. Los resultados muestran que el 10,5\% de los estudiantes consumió benzodiacepinas sin prescripción médica alguna vez en la vida. Del total, el 6,1\% consumió en el último año y el 3,9\% usan actualmente. El Diazepan fue la BZD más usada sin prescripción médica, siendo la farmacia el local de mayor acceso. Entre los principales motivos para el consumo de benzodiacepinas se encuentran: insomnio, ansiedad, estrés, depresión y problemas familiares o económicos. El uso de benzodiacepinas con propósitos no-medicinales está relacionado a problemas de pérdida de la memoria, síndrome de abstinencia y sedación. Cuando son combinados con alcohol u otras drogas, pueden llevar a la coma y a la muerte. Este estudio muestra las graves consecuencias que las benzodiacepinas pueden ocasionar cuando utilizados por estudiantes de enfermería en Ecuador.

DESCRIPTORES: automedicación; receptores GABA-A; estudiantes de enfermería

\section{CONSUMO DE BENZODIAZEPINOS SEM PRESCRIC̄̃̃O MÉDICA ENTRE ESTUDANTES DO PRIMEIRO ANO DA ESCOLA DE ENFERMÁGEM DA UNIVERSIDADE DE GUAYAQUIL, EQUADOR}

O objetivo deste estudo foi determinar o consumo de benzodiazepinos sem prescrição em estudantes do primeiro ano de enfermagem de uma universidade pública do Equador. Trata-se de um estudo transversal, descritivo e exploratório, com abordagem quantitativa. Um questionário foi usado para coleta dos dados. A população estudada foi composta por 181 estudantes. Os resultados mostram que 10,5\% dos estudantes consumiram benzodiazepinos sem prescrição médica alguma vez na vida. Do total, 6,1\% consumiram no último ano e 3,9\% usam atualmente. O Diazepan foi a BZD mais usada sem prescrição médica, sendo a farmácia, o local de maior acesso. Entre os principais motivos para o consumo de benzodiazepinos encontramse: insônia, ansiedade, estresse, depressão e problemas familiares ou econômicos. O uso de benzodiazepinos com propósitos não-medicinais está relacionado a problemas de perda da memória, síndrome de abstinência e sedação. Quando são combinados com álcool ou outras drogas, podem levar ao coma e à morte. Este estudo mostra as graves conseqüências que os benzodiazepinos podem ocasionar quando utilizados por estudantes de enfermagem no Equador.

DESCRITORES: automedicação; receptores de GABA-A; estudantes de enfermagem

\footnotetext{
${ }^{1}$ Teaching Diploma in Nursing, M.Sc. in Higher Education, Faculty, University of Guayaquil, School of Nursing, Ecuador; ${ }^{2}$ PhD, Faculty, e-mail: amiasso@eerp.usp.br, crtirapelli@eerp.usp.br. University of São Paulo at Ribeirão Preto, College of Nursing, WHO Collaborating Centre for Nursing Research Development, Brazil
} 


\section{INTRODUCTION}

The consumption of medicines without prescription has been a frequent behavior in every culture and period. "This behavior has been transformed into an ability to satisfy health necessities, to share medicines with family members or from the social circle and to use medicines left from other prescriptions $^{(1)}$." $^{\prime \prime}$

The illegal consumption of benzodiazepines entails health risks because of a lack of professional orientation. This situation can hide a disease, complicate a symptomatological state and consequently delay the recovery. For instance, it is important to say that isolated auto-medication produces harmful and undesirable consumption. These drugs, which belong to a group of small tranquilizers, due to their wide therapeutic power, are the reason for abuse and are prescribed in excess in general medical practice ${ }^{(2-3)}$.

As depressants of the central nervous system (CNS), they develop tolerance in few weeks of treatment. Sedation and sleepiness can deteriorate mental and motor functions, reduce the capability of attention, concentration and decision and cause anterograde amnesia. Therefore, it is important to call attention to these effects, which can be presented as an overdose when combined with other depressants of the $\mathrm{CNS}^{(2)}$.They produce physical dependence when used for a long time and, when interrupted in an abrupt way, this can cause the abstinence syndrome ${ }^{(4)}$. Acute intoxication, either accidental or suicidal, with these drugs is very frequent, even though mortality by overdose is very low (less than $1 \%)^{(5)}$. They are also used for phobic confusion, panic, post-traumatic stress, convulsive disorders, syndrome of alcohol abstinence and barbiturates, in insomnia crises and, also, in cases of anxiety (used worldwide) ${ }^{(6)}$.

There is much information about drugs like alcohol, tobacco, marijuana and cocaine, among others. Statistics about usage are emphasized, despite the lack of interest by researchers, not only due to their importance, but also due to the consequences they entail. The lack of qualitative data leads to a consequent lack of information about the matter.

The free sale of medicine has risen worldwide and institutions in control are not severe enough to stop this growth, which is characterized as epidemic. This fact evidences that auto-medication is present in the population in general: workers, housewives, medical students, university students and professionals - highlighting health care professionals, among whom this behavior is regular. They have knowledge, more access to information about health and also a relation to medicines, which have been the main factors to make this practice regular.
Traditionally, Latin America has been considered one of the regions that provides and promotes transport of drugs to the world. However, in recent years, it has experienced a quick change, ceasing to be a productive region and starting to be a consumer ${ }^{(7)}$. Data are found about the rise of the illegal use of tranquilizers and amphetamines in the urban and peripheral areas of Latin America, a situation that has been promoting prescription without medical permission or the irrational prescription of medicines prepared with psychotropic substances, developing dependence ${ }^{(8)}$. These are drugs of easy access in drugstores and pharmacies, because they are an alternative to make various health problems better, noticing a generalized tendency towards automedication. Therefore, they change from one medicine to another according to doses and frequencies they establish.

International authorities consider that diagnosing drug consumption in the school population represent one of the most efficient instruments to obtain knowledge, not only about the current problem situation, but also as a way of previewing drug consumption in the future ${ }^{(9)}$.

In this sense, with a view to updating information, exchanging experiences and promoting scientific knowledge, research has been performed about drugs in the population in general, students and workers from South and Central America since the beginning of 2000 . It was reported that benzodiazepine tranquilizers, such as Diazepam and Alprazolam, without prescription are also worrying. The countries with the highest proportion are Paraguay, Bolivia and Colombia, with $7.1 \%, 7 \%$ and $6.4 \%$ respectively ${ }^{(10)}$.

Studies in seven countries in 2003 showed that the most consumed drug in Paraguay is "Jarra Loca" (a mixture of alcohol and tranquilizers), which is a dangerous combination because it enhances the sedative effects. In the Dominican Republic, the tranquilizers consumed without prescription appear with high levels, $12.8 \%$ for women and $6.5 \%$ for men ${ }^{(11)}$. It is a problem not only at schools, because an increase has been noticed inabuse among adults - especially benzodiazepines, which are mixed with alcohol most of the times ${ }^{(12)}$.

In Ecuador, in 1998, the prevalence of tranquilizer consumption at school was $6.6 \%$, more than stimulants $(3.6 \%)$, and the average age was 14.3 years old. As to gender, the consumption behavior did not show a significant difference, with $8.2 \%$ for females and $8 \%$ for males. However, $23 \%$ of the interviewed parents used pills for anxiety (to sleep, to calm down, to feel good, among others) ${ }^{(9)}$. The parents' behavior can be considered an example that influences their children's behavior. 
In 2002, the prevalence of tranquilizers consumption in secondary education students in Ecuador was $5.9 \%$, with 13.6 years as the average age for the first consumption, emphasizing that $51.1 \%$ of the interviewed population used tranquilizers with prescription ${ }^{(9)}$, a situation which reveals that a high percentage of students use these substances in a suspicious way. Research in that country performed in 2005 highlights that the use of tranquilizers without prescription was higher for stimulants $(6.1 \%)$, with the age for the first consumption at 13 years and 4 months $^{(9)}$.

Nursing students, as young people with a professional future in health care, find themselves in an inflexible cultural context that promotes contact with legal and illegal drugs ${ }^{(12)}$. Therefore, it is a challenge to research this human resource because the population is vulnerable to auto-medication.

Teaching practice has allowed the researcher to observe students' behavior: their desires, problems, insecurities, fears and anxiety about the possibility of not fighting against them, besides taking decisions. These are situations that sometimes lead to medication use with the objective of relieving moments of discomfort instantaneously. In view of these factors, this study aimed to determine the use of BZD without prescription in first-year nursing students, considering sociodemographic characteristics, types of benzodiazepines, frequency, dose, reason and ways of access.

\section{METHODOLOGY}

This is a cross-sectional, descriptive and exploratory study with a quantitative focus, carried out at the Nursing School of the University of Guayaquil, Ecuador. The population was composed of 181 first-year nursing students, of both genders, over 18 years old, regularly enrolled at the school and attending classes as part of the Regular and Complementary Groups. In the first group, the majority do not work, having enough time to accomplish their academic tasks. However, the second group, also denominated professionalization group of nursing assistants, was created to promote access to the bachelor's degree and improve knowledge and care quality, with a view to renewing the nursing group. Those students play many roles (father, mother, workers and students). The studies are totally paid for by the students (enrolments and installments).

The interview instrument was a questionnaire about the history of psychoactive drugs $^{(13)}$, which was adapted to the necessities of the study, with structured questions, consisting of characteristics of the interviewed person, general and specific questions related to BZD consumption, consisting of 25 items in total.

The study was approved by the Bioethical Committee of the University. The participants were informed about the research, signing the free and informed consent term. As for the statistics, frequencies and percentages were used, obtained by Microsoft Excel. The research results were presented in tables and graphs.

\section{RESULTS AND DISCUSSION}

Participants were 181 first-year nursing students, classified into the Regular and Complementary Groups.

Table 1 showsthat 110 (60.8\%) students answered that they did not consume BZD and that 20 $(11 \%)$ did not answer the question. The sum of both shows a meaningful percentage $(71.8 \%)$, which can suggest that the answers were not sincere. Fourteen students had consumed BZD with prescription (7.7\%); 19 (10.5) used these products at least once without prescription; $11(6.1 \%)$ used them in the last year and until the moment (during the interviews, 7 (3.9\%) students). These results coincide with international studies $^{(10,14)}$ and, at a local level, with an experimental study performed among university students ${ }^{(15)}$.

Table 1 - BZD consumption in first-year students. Guayaquil, Ecuador, 2007

\begin{tabular}{lcccccc}
\hline \multicolumn{1}{c}{ BZD use } & \multicolumn{2}{c}{$\begin{array}{c}\text { Regular } \\
\text { Group }\end{array}$} & \multicolumn{2}{c}{$\begin{array}{c}\text { Complementary } \\
\text { Group }\end{array}$} & \multicolumn{2}{c}{ Total } \\
& $\mathbf{n}$ & $\%$ & $\mathbf{n}$ & $\%$ & $\mathbf{n}$ & $\%$ \\
\hline With prescription & 5 & 4.1 & 9 & 15.5 & 14 & 7.7 \\
Without Prescription & & & & & & \\
$\quad$ Used some time & 11 & 8.9 & 8 & 13.8 & 19 & 10.5 \\
in the last year & 6 & 4.9 & 5 & 8.6 & 11 & 6.1 \\
$\quad$ Use presently & 3 & 2.4 & 4 & 6.9 & 7 & 3.9 \\
Do not use & 86 & 69.9 & 24 & 41.4 & 110 & 60.8 \\
Did not answer & 12 & 9.8 & 8 & 13.8 & 20 & 11 \\
Total & 123 & 100 & 58 & 100 & 181 & 100 \\
\hline
\end{tabular}


As for the consumption of benzodiazepines without prescription according to gender, a gap is noticed, with high female consumption when compared to men, 35 (94.6\%) respectively. These are meaningful results that coincide with other studies, in which women prefer the consumption of medication drugs without prescription ${ }^{(12,16)}$.

Table 2 discloses that, among 20 students from the Regular course who reported BZD consumption without prescription, five worked, while 17 students from the Complementary course worked and were Nursing Assistants. The places of work were hospitals, $12(70.6 \%)$ at the emergency and ICU; $47.1 \%$ in high-level critical units and units with high levels of stress, such as psychiatry; and 8 students worked night shifts. These facts can affect their academic development, causing alterations and dysfunctions during the day due to the paperwork, besides their low salary. It is easy to understand the economic and emotional overload they go through, a situation that can lead to career desertion - a phenomenon growing in universities, considering that the students look for jobs or occupations that can offer them more respectable economic, social and work conditions ${ }^{(17)}$.

Table 2 - Use of BZD without prescription according to socioeconomic variables among first-year Nursing students. Guayaquil, Ecuador, 2007

\begin{tabular}{|c|c|c|c|c|c|c|}
\hline \multirow[t]{2}{*}{ Variables } & \multicolumn{2}{|c|}{$\begin{array}{c}\text { Regular } \\
(n=5)\end{array}$} & \multicolumn{2}{|c|}{$\begin{array}{c}\text { Complementary } \\
(n=17)\end{array}$} & \multicolumn{2}{|c|}{$\begin{array}{l}\text { Total } \\
(n=22)\end{array}$} \\
\hline & $\mathbf{n}$ & $\%$ & $\mathbf{n}$ & $\%$ & $\mathbf{n}$ & $\%$ \\
\hline \multicolumn{7}{|l|}{ Work place } \\
\hline Hospital & 1 & 20 & 12 & 70.6 & 13 & 59.1 \\
\hline Health Care Unit & 0 & 0 & 1 & 5.9 & 1 & 4.5 \\
\hline Doctor's office & 2 & 40 & 1 & 5.9 & 3 & 13.6 \\
\hline Clinic & 0 & 0 & 3 & 17.6 & 3 & 13.6 \\
\hline Others & 2 & 40 & 0 & 0 & 2 & 9.1 \\
\hline \multicolumn{7}{|l|}{ Unit } \\
\hline Emergency & 1 & 20 & 4 & 23.5 & 5 & 22.7 \\
\hline $\mathrm{ICU}$ & 0 & 0 & 4 & 23.5 & 4 & 18.2 \\
\hline Psychiatry & 1 & 20 & 3 & 17.6 & 4 & 18.2 \\
\hline Clinic & 1 & 20 & 3 & 17.6 & 4 & 18.2 \\
\hline Gynecology & 1 & 20 & 1 & 5.9 & 2 & 9.1 \\
\hline Pediatrics & 1 & 20 & 2 & 11.8 & 3 & 13.6 \\
\hline \multicolumn{7}{|l|}{ Position } \\
\hline Assistant & 2 & 40 & 17 & 100 & 19 & 86.4 \\
\hline Attendant & 3 & 60 & 0 & 0 & 3 & 13.6 \\
\hline \multicolumn{7}{|l|}{ Working hours } \\
\hline $7-13$ & 2 & 40 & 3 & 17.6 & 5 & 22.7 \\
\hline $7-15$ & 0 & 0 & 6 & 35.3 & 6 & 27.3 \\
\hline $15-23$ & 1 & 20 & 0 & 0 & 1 & 4.5 \\
\hline $23-7$ & 2 & 40 & 8 & 47.1 & 10 & 45.4 \\
\hline \multicolumn{7}{|l|}{ Monthly Wage \$ } \\
\hline Less than $100 \$$ & 1 & 20 & 2 & 11.8 & 3 & 13.6 \\
\hline $101-200 \$$ & 2 & 40 & 7 & 41.2 & 9 & 40.9 \\
\hline $201-300 \$$ & 1 & 20 & 5 & 29.4 & 6 & 27.3 \\
\hline $301-400 \$$ & 1 & 20 & 2 & 11.8 & 3 & 13.6 \\
\hline 401 or more\$ & 0 & 0 & 1 & 5.9 & 1 & 4.5 \\
\hline
\end{tabular}

According to the data in Table 3, the most consumed BZD without prescription is Diazepam, with $40 \%$ for both groups of students, followed by Alprazolam with $20 \%$ for the Regular and $17.6 \%$ for the Complementary Group. These results coincide with studies performed in other countries ${ }^{(14)}$. Other studies mentioned the use of Flunitrazepam.

Table 3 - Most consumed BZD without prescription in first-year students, Guayaquil, Ecuador, 2007

\begin{tabular}{lcccccc}
\hline \multicolumn{1}{c}{\begin{tabular}{c} 
Most consumed \\
\multicolumn{1}{c}{ BZD }
\end{tabular}} & \multicolumn{2}{c}{$\begin{array}{c}\text { Gegular } \\
\text { Group }\end{array}$} & $\mathbf{n}$ & $\%$ & $\mathbf{c} \begin{array}{c}\text { Complementary } \\
\text { Group }\end{array}$ & \multicolumn{2}{c}{ Total } \\
& $\mathbf{n}$ & $\%$ & $\mathbf{n}$ & $\%$ \\
\hline Clonazepam & 2 & 10 & 2 & 11.8 & 4 & 10.8 \\
Lorazepam & 2 & 10 & 2 & 11.8 & 4 & 10.8 \\
Diazepam & 8 & 40 & 7 & 41.1 & 15 & 40.6 \\
Alprazolam & 4 & 20 & 3 & 17.6 & 7 & 18.9 \\
Bromazepam & 2 & 10 & 2 & 11.8 & 4 & 10.8 \\
Ketazolam & 1 & 5 & 1 & 5.9 & 2 & 5.4 \\
Others & 1 & 5 & 0 & 0 & 1 & 2.7 \\
Total & 20 & 100 & 17 & 100 & 37 & 100 \\
\hline
\end{tabular}

As for the reason for the consumption, 35.3\% of the students from the complementary course and $25 \%$ from the regular course say that the reason is because of insomnia and sleep disorders, the most found symptoms in research. The occurrence of these symptoms is high and damages the quality of life, presenting negative consequences for the family, work and social activities ${ }^{(18)}$. Anxiety is the second cause of usage, followed by depression and stress, besides family problems, economic situation, work and study (Figure 1).

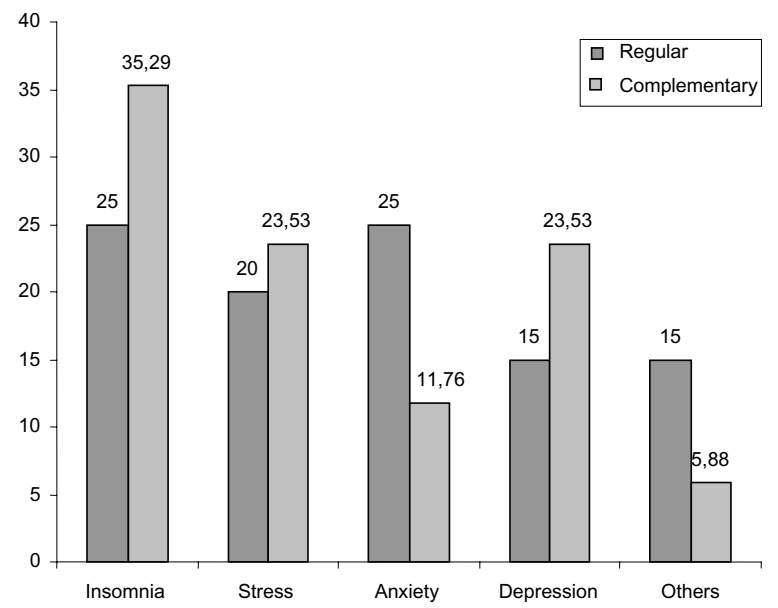

Figure 1 - Reason for BZD consumption without prescription, first-year students, EEUG, Guayaquil, 2007

Figure 2 evidences that $50 \%$ of the students obtained BZD in pharmacies, showing the same tendency and values previously observed ${ }^{(14)}$. The role of the pharmacies as medicine "sellers" must be 
investigated and controlled to reduce irresponsible consumption of medicines ${ }^{(19)}$. Other ways of obtaining drugs are: friends, medicine boxes and access to medical samples among students from the Complementary group, who work at the health institutions.

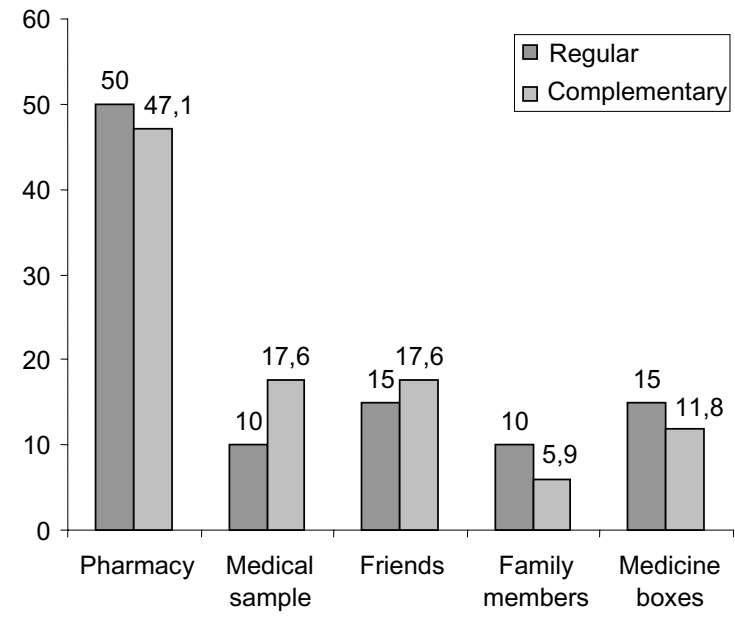

Figure 2 - Place of BZD acquisition without prescription in first-year students, EEUG, Guayaquil, Ecuador, 2007

\section{CONCLUSIONS}

- Auto-medication with BZD is a behavior present in the nursing students;

- Most of the students in the research are young, especially the ones from the Regular group. In the Complementary Group, besides accomplishing their academic activities, students work as nursing assistants in hospitals performing in critical areas, such as the emergency and the ICU, stress-promoting units like psychiatry, night shifts, with low salaries that do not allow them to cover their basic needs. These factors may lead to consumption without prescription;
- Diazepam was the most consumed benzodiazepine without prescription and the pharmacy is the most frequent place of access, followed by friends and medical samples;

- The main reasons for consumption were: insomnia, anxiety, stress, depression and other problems, such as family, economic situation, work and study;

- The period of consumption was 3.6 months on the average, characterized by variable frequency and dose, which shows the lack of information about the danger of auto-medication and its undesirable effects. The only way to change this situation is to increase future nursing professionals' knowledge, because they are expected to give importance to the risks and benefits at the moment of care delivery to patients, family and community.

\section{ACKNOWLEDGEMENTS}

Acknowledgements to the Inter-American Drug Abuse Control Commission/CICAD of the Sub-Secretary of Multidimensional Security at the Organization of American States/OAS, the Brazilian Anti-Drugs Secretary/SENAD, faculty members at the University of São Paulo at Ribeirão Preto College of Nursing, WHO Collaborating Centre for Nursing Research Development, Brazil, to the population who participated in the studies and to the representatives from eight Latin-American countries who participated in the I and II On-Line Specialization Program for Research CapacityBuilding on the Drugs Phenomenon-PREINVEST, offered in 2005/2006 by the University of São Paulo at Ribeirão Preto College of Nursing, as a distance education course.

\section{REFERENCES}

1. De Loyola A, Uchoa E. Prevalecía y factores asociados a automedicación. Resultados del Proyecto de Bambuí. Rev Saúde Pública 2002; 36(1):55-62.

2. Nordt SP, Clark RF. Midazolam: A review of therapeutic uses and toxicity. Emergency Med 1997; 15(3):357-65.

3. Petitjean S, Ladewig D, Meier CR, Amrein R, Wiesbeck GA. Benzodiazepine prescribing to the Swiss adult population: results from a national survey of community pharmacies. Int. Clin Psychopharmacol 2007; 22 ( 5$): 292-8$.

4. Pagel F, Parnes BL. Medications for the treatment of sleep disorders: an overview. J Clin Psychiat 2001; 3:118-25.
5. Velasco A, San Román L, Martínez SR, Cadavid MI. Farmacología Fundamental. España: McGraw HillInteramericana; 2003. p. 268-73.

6. Lehne RA. Pharmacology for Nursing Care. 5. ed. Philadelphia, Pa: W.B. Saunders; 2003.

7. López B. Patrones de Consumo y Oferta Asistencial Unión Europea, Europa Central y Oriental, América del Norte y Latinoamérica. Barcelona: Dianova Internacional; 2001.

8. Druetta G. Situación de América Latina y el Caribe en materia de producción y tráfico ilícito de drogas y delitos conexos [database na Internet]. El Salvador: Instituto de Drogodependencia. Universidad del Salvador; [Acesso em 2005 abril 1] Disponivel em: http://ar.geocities.com/ laotraverdad/salvador/drog5604.html 
9. Oficina de Naciones Unidas Contra las Drogas y el Delito. Segunda Encuesta Nacional Sobre Consumo de Drogas en Estudiantes de Enseñanza Media. Ecuador: OEA; 2006.

10. Oficina de Naciones Unidas Contra las Drogas y el Delito. Jóvenes y Drogas en Países Sudamericanos: Un desafío para las Políticas Públicas. Primer Estudio Comparativo Sobre Uso de Drogas en Población Escolar Secundaria. Perú: Tetis Graf E.I.R.L.; 2006.

11. Organización de los Estados Americanos.Informe comparativo de 7 países, Encuestas a Escolares a Nivel Nacional: el Salvador, Guatemala, Nicaragua, Panamá, Paraguay, República Dominicana y Uruguay 2003. Washington D.C: OEA; 2004.

12. Ortega N, Osorio E, Pedrão LJ. El significado de drogas para el estudiante de enfermería según el modelo de creencias en salud de Rosenstock. Rev Latino-Am Enfermagem 2004; 12 (no.spe):316-23.

13. Sobell M, Sobell LC. Problem Drinkers: Guided self-change treatment. London: Guildford Press; 2003

14. Rueda FP. Automedicación Psiquiátrica en una muestra del Bo Batahola Norte,durante agosto a octubre en el año 2006. [Tesis Especialista en Psiquiatria]. Nicaragua: Universidad Nacional Autonoma de Nicaragua Facultad de Ciencias Médicas; 2006.

15. Piedra K, Pillon S. Relación Drogas y Comportamiento Violento entre dos Universidades de Brasil y Ecuador. Proyecto de Investigación de Enfermería para la Reducción y Demanda de Drogas Lícitas e Ilícitas en América Latina. Guayaquil- Ecuador: OEA; 2004.

16. Alarcon R. Trastornos de angustia, para fenómeno emocional, definición, clasificación. 2ed. Lima: Fondo Editorial UNMSM; 1998.

17. Enfermería 21 [homepage na Internet]. Archivo noticias 2007 [acesso 2007 Setembro 17]. Enfermeras de todo el mundo alertan sobre la escasez de profesionales; [2 telas]. Disponível em: www.enfermeria21.com/contenidos/noticias/ titulares/archivo/listado.php.

18. Sarrais F, Manglano PC. El insomnio. An Sist Sanit Navar 2007; 30 (Supl 1): 121-34.

19. Soto E, Roa Y. Patrones de Autoatencion y Automedicación entre la Población Estudiantil Universitaria de la Ciudad de Puebla. Ciencia y Cultura 2004; 11(55$6): 43-51$. 